\title{
Determinants of pricing objectives and price flexibility policies of pork-based agro-businesses in Mashonaland Central province, Zimbabwe
}

\begin{tabular}{|c|c|}
\hline \multicolumn{2}{|c|}{$\begin{array}{l}\text { Saul Ngarava }{ }^{1} \\
\text { Abbyssinia Mushunje }^{1} \text { — }\end{array}$} \\
\hline \multicolumn{2}{|c|}{$\begin{array}{l}\text { Affiliations: } \\
{ }^{1} \text { Department of Agricultural } \\
\text { Economics and Extension, } \\
\text { Faculty of Science and } \\
\text { Agriculture, University of Fort } \\
\text { Hare, South Africa }\end{array}$} \\
\hline \multicolumn{2}{|c|}{$\begin{array}{l}\text { Corresponding author: } \\
\text { Saul Ngarava, } \\
\text { 201501225@ufh.ac.za }\end{array}$} \\
\hline \multicolumn{2}{|c|}{$\begin{array}{l}\text { Dates: } \\
\text { Received: } 27 \text { July } 2017 \\
\text { Accepted: } 07 \text { Nov. } 2017 \\
\text { Published: } 18 \text { Apr. } 2018\end{array}$} \\
\hline \multicolumn{2}{|c|}{$\begin{array}{l}\text { How to cite this article: } \\
\text { Ngarava, S. \& Mushunje, A., } \\
2018 \text {, 'Determinants of } \\
\text { pricing objectives and price } \\
\text { flexibility policies of } \\
\text { pork-based agro-businesses } \\
\text { in Mashonaland Central } \\
\text { province, Zimbabwe', } \\
\text { South African Journal of } \\
\text { Economic and Management } \\
\text { Sciences 21(1), a2029. } \\
\text { https://doi.org/10.4102/ } \\
\text { sajems.v21i1.2029 }\end{array}$} \\
\hline \multicolumn{2}{|c|}{$\begin{array}{l}\text { Copyright: } \\
\text { ๔ 2018. The Authors. } \\
\text { Licensee: AOSIS. This work } \\
\text { is licensed under the } \\
\text { Creative Commons } \\
\text { Attribution License. }\end{array}$} \\
\hline \multicolumn{2}{|l|}{ Read online: } \\
\hline 品部品 & $\begin{array}{l}\text { Scan this QR } \\
\text { code with your } \\
\text { smart phone or } \\
\text { mobile device } \\
\text { to read online. }\end{array}$ \\
\hline
\end{tabular}

Background: The article focuses on the pricing strategies that are used in a dynamic institutional environment of land reform and indigenisation policies. Zimbabwe underwent a land reform incorporating new players in the pork agribusinesses, as well as indigenisation, altering agrobusiness decision-making structures. One such decision is effective pricing.

Aim: The objective of the study was to highlight the determinants of utilising a particular pricing objective and price flexibility policy in the Zimbabwean pork industry.

Setting: The study examined the pricing objectives and price flexibility policies of pig producers, pork abattoirs and butcheries in Mashonaland Central province, Zimbabwe.

Methods: The study used a cross-sectional, descriptive and quantitative survey of pig producers, pork abattoirs and pork butcheries. A structured precoded questionnaire-based interview of 166 pig producers, 6 pork abattoirs and 24 butchers was used as the data collection tool and method. A logit model was used for analysis, ascertaining determinants of a binary choice model.

Results: The study found that agribusinesses' pricing objectives were determined by the product portfolio, margin, merchandise handled, distance the furthest buyer travels and consideration of other industry players' pricing at the $p<0.01$ level. Furthermore, factors such as seasonality in April to September sales, quality considerations $(p<0.05)$, frequency of retailers and size considerations $(p<0.1)$ were also significant determinants of pricing objectives. Also, the agribusinesses' price flexibility policies were shown to be determined by agribusiness location, average weight of merchandise, frequency of individual customers, size consideration and consideration of other industry players' pricing at the $p<0.01$ level. In addition, margin, frequency of abattoir buyers $(p<0.05)$ as well as pork product portfolio $(p<0.1)$ were also observed to be major factors towards a flexible pricing policy.

Conclusion: The results suggest that pork industry players in Zimbabwe are myopic in their pricing strategies, having factors such as product portfolio, margin, merchandise handled and considerations of other industry players' strategies as dualistically determining pricing objective and price flexibility policy utilised. The study recommends that pork industry players shift from myopic pricing objectives of profit and survival and devise new pricing strategies based on sales and competitive pricing. There is also need for less rigidity in flexible price policies to take advantage of the dynamic external environment.

\section{Introduction}

Price is the amount of currency that is charged and foregone in a swap for a good or service (Dwyer \& Turner 2003; Kotler et al. 1999; McDaniel, Lam \& Hair 2008; Perreault \& McCarthy 2002). Pricing is an essential part of a more encompassing and universal marketing strategy and consequently organisations need to devise an interconnected and integrated marketing strategy, with a comprehensive pricing strategy as part of such an endeavour (Indounas 2006; Kotler et al. 1999). Come the year 2050, the African meat market will be 34.8 million tonnes, a $145 \%$ increase in demand relative to the 2005-2007 levels, fuelled by urbanisation, rapid population growth and increase in real per capita incomes (McGlone 2013; Pica-Ciamarra et al. 2013; Von Braun 2010). Pork production will increase by $3.3 \%$ to 1.5 million tonnes in Africa, with southern Africa increasing by $2.9 \%$, constituting $37.1 \%$ of Africa's market share (Pica-Ciamarra et al. 2013). Effective positioning and livestock sector strategy formulation becomes imperative if industries are to take advantage of such sustained and increased consumption, business and market opportunities. A major and overlooked strategy that agricultural enterprises need to pursue to 
capture full value is effective pricing (Chikweche \& Fletcher 2012; Dodor 2013; Ngarava 2016). Uva (2009) identifies that price directs supply and demand, signals to customers, shifts possession and avails income to agribusinesses. According to Bakucs, Falwoski and Ferto (2013), in developing meat products, setting the right price is particularly difficult. Dodor (2013) supports this, further indicating the difficulty especially at the farmer level. Chikweche and Fletcher (2012) exemplify this through indicating that the smaller the agribusinesses the less the opportunity for bargaining power and the more identical the pricing strategies.

According to Ingenbleek, Frambach and Verhallen (2010) as well as Barnard et al. (2012), agribusinesses utilise an array of pricing strategies and practices, directly influencing quantities sold and revenue generated. Indounas (2006) supports this, highlighting the direct relationship between price and profit, with other enterprise decisions relating to costs, with pricing decisions being flexible and executed relatively quickly. However, Chikweche and Fletcher (2012) found difficulty in price development compounded by neglect in its formulation, opting for convenient strategies (Shipley \& Jobber 2001). This is true for Zimbabwean agribusinesses. Agriculture in Zimbabwe accounts for $13.82 \%$ of the country's GDP (ZIMSTAT 2014b), with average growth rate of $4.1 \%$. The sector accounts for $23.7 \%$ of value of imports and $30.4 \%$ of value of exports, employing $56.9 \%$ of the formal workforce (African Statistics Yearbook 2014; ZIMSTAT 2014a). The livestock sector contributes $15 \%-25 \%$ of total agricultural output (Tawonezvi et al. 2004; WTO 2011). The pork sub-sector accounts for $3.5 \%$ of the country's total livestock assets, with communal farmers accounting for $88.2 \%$ of the pig producers, mainly for subsistence production (Chazovachii 2012; FAOSTAT 2014). According to Mutambara (2013), pricing has been one of the factors that has had an effect on the pork industry in Zimbabwe. Khumalo (2014) concurred, opining that the meat sector pricing should be competitive and attractive to external markets.

Putting Mbogoh's (1992) assertion of the continual reassessment of pricing decisions, processes and methods, as well as the structural adjustments in Zimbabwe in terms of land reform (Mutambara 2013) and indigenisation policies (Netherlands Ministry of Economic Affairs 2014), into perspective, it becomes imperative, therefore, to ascertain what pricing strategies are being utilised and what are the likely factors that determine choice of those strategies. It is against this background that the current study seeks to highlight the determinants of utilising a particular pricing objective and price flexibility policy in the Zimbabwean pork industry. There has been little research on pricing (Hinterhuber 2004), with most studies being descriptive and non-cumulative (Ingenbleek 2007). De Toni et al. (2016) confirm that less than $2 \%$ of research in leading journal output concerns pricing studies. This has mainly been due to the complexity and confusion concerning fundamental decisions of the pricing process. Most of the pricing research has been in the economics and business field with little attention on the agricultural sector, especially at the producer level.
Furthermore, the Zimbabwean pork sub-sector has endured restructuring both at the producer and processor levels. The land reform in Zimbabwe has introduced new farmers in pig production, with the indigenisation policy restructuring agribusiness decision-making mechanisms. Highlighting pricing objectives and price flexibility policy decisions is thus imperative in ascertaining the status quo in terms of these decisions as well as aiding firms in the industry (both new and old) in making more informed decisions. Ward, Feuz and Schoreder (1999) concur, identifying the need for pricing research necessitated by structural and behavioural changes in agriculture. Carricano (2014) indicates that such price strategy findings have implication both from the theoretical and practical viewpoints. Theoretically, it extends previous agribusiness pricing strategy studies through a more informed pricing decision process. Identifying the key determinants will also assist the agribusinesses in the firmspecific internal self-assessment of the pricing strategies as well as contingencies available and how they affect the industry (Carricano 2014). Information gathered is useful for extension officers at the pig producer levels, as well as agricultural associations which can also utilise the information gathered to inform its members of options in pricing strategy.

\section{Literature review: Pricing objectives and price flexibility policies in agro- based industries}

According to Kotler (2002), pricing objectives can be grouped into profit, sales and status quo, even though Shipley and Jobber (2001) highlight the existence of up to 21 pricing objectives. In profit-oriented pricing objectives, a precise level is set as an objective. This can be through a target return or profit maximisation, where as much profit as possible is acquired. In Austria, Jumah (2000) found chicken and pork industries utilising mark-up pricing for profit maximisation. Schinckel (2005) supports the objectives of most pork industry players wanting to maximise returns. Sales-oriented objectives on the other hand disregard profit, aspiring for some level of market share, unit sales or dollar sales (Ngarava 2016). Volpe et al. (2015) found such sales-oriented pricing being practised in the US pork industry, with the pork price increases and decreases highly dependent on promotional and supplier prices, with much disregard for competitor prices. In status quo pricing, the objective is either to meet, stabilise or avoid the competition. In the US, Buhr (2004) identified pig industry enterprises utilising competitive pricing objectives. Bojnec (2002) in Slovenia as well as Bakucs and Ferto (2005) in Hungary also identified the use of competitive pork pricing mechanisms. Although pricing objectives could be identified in the literature, there has been little literature concerning the determinants of choice of objective. One reason could be the contextual nature of these determinants, being case specific. Shipley and Jobber (2001) subdivide determinants of pricing objectives into three: the businesses' cost structure, competition and customer demand. Smit (2012) identifies that these determinants are due to internal 
and external environments of the enterprises, thus a onesize-fits-all does not apply. Adugna (2006) and Teklewold et al. (2009) identified determinants in livestock pricing but aside from the fact that their studies were in Ethiopia, they were focused more on red meat livestock, mainly looking at the price levels relative to the pricing objectives. This necessitates context-based evaluations of pricing objectives, an objective the current study sought to achieve.

Price flexibility policies are two tiers: one price or flexible price. According to Li and Sexton (2013), in a one price policy, pricing is much easier as the same price is offered to all customers in equal numbers under the same conditions. On the other hand Perreault and McCarthy (2002) highlight a flexible pricing policy as offering similar quantities to different customers at different prices. Mbogoh (1992) identified informal livestock markets exhibiting more price flexibility, with the one price policy rigidity in formal markets. In the US, a 'price window', especially in contract pricing, is utilised where a maximum and minimum price is set, with price fluctuations within these extremities accepted as the market price (Kenyon \& Purcell 1999; Buhr \& Kunkel 1999; Unterschultz et al. 1997). Shao and Roe (2002) further differentiated a fixed and moving window in the same US pork market. The price flexibility policy studies also highlight how price determination is also area and context specific, with formalised agribusinesses exhibiting a one price policy while the informal ones utilise flexible prices. Carricano (2014) indicates that environmental factors tend to determine price flexibility. These price flexibility policies might be due to the agribusiness characteristics themselves where wet markets are devoid of institutional structures such as contract pricing, storage infrastructures such as refrigeration with a dynamic customer base, thus price is reached through negotiations. Formal markets are characterised with a constant demand through formalised contracts, thereby able to fix a price, with improved infrastructural storage technologies. Be that as it may, studies concerning price flexibility policies have also been few and far between, especially in the Zimbabwean pork sub-sector. This has necessitated the current study, which seeks to ascertain the determinants of pricing objectives and price flexibility policies in the Zimbabwean pork industry.

\section{Methodology \\ Description of study area}

The study was carried out in Mashonaland Central province of Zimbabwe (Figure 1). Mashonaland Central province is agro-based, lying in the north-east part of the country with an area of $28347 \mathrm{~km}^{2}$ and a population of 1152520 , representing $8.23 \%$ of the total Zimbabwean population (ZIMSTAT 2014a).

Agriculture is the main economic activity in Mashonaland Central province, playing a key part in the social and economic development through provision of affordable food and employment, contributing to poverty reduction (Musemwa 2011). Relative to its agro-ecological location, the province is suited for crop production because of the average to above average rainfall (750 mm-1000 mm annually) contained therein, making pig production a secondary enterprise mainly at the smallholder level and enticing because of the proximity to input production of soya bean and maize. The land reform programme in Zimbabwe has influenced land ownership, having a direct bearing on agrobased activities through influence of security and investment in infrastructure (Chisango 2010). The programme resulted in $152 \mathrm{~A}_{1}$ pig producers with temporary production licences on less than 10 hectares, $193 \mathrm{~A}_{2}$ pig producers having 99-year lease agreements with more than 30 hectares of land, 92 small-scale commercial producers, 14 large-scale producers and 8354 communal farmers. Mashonaland Central province has 14 registered abattoirs, $11.38 \%$ of the country's total. The province has 50 registered butchers, but the total number of butchers is potentially higher because of the existence of unregistered butchers (Njaya 2014; Scoones 2008). The power shortages bedevilling the country, ultimately affecting butchery operations, have relegated most of the butcheries to peri-urban and urban areas. The study units were pig producers, pork abattoirs and pork butcheries.

\section{Sampling technique}

The study used a cross-sectional, descriptive and quantitative survey of pig producers, pork abattoirs and pork butcheries. Purposive sampling was used to select Mashonaland Central province because of the high number of pig producers, pork abattoirs and butchers. The total population of the study was 518, consisting of $152 \mathrm{~A}_{1}$ producers, $193 \mathrm{~A}_{2}$ producers, 92 small-scale commercial producers, 14 large-scale commercial producers, 14 abattoirs and 53 retailers. Random sampling was used to select 226 respondents through Yamane's (1967) method, as shown below:

$$
n=\frac{N}{1+N(e)^{2}}
$$

$n=$ sample size; $N=$ population size, 518 in this case, and $e=$ degree of precision (95\%).

$n=\frac{518}{1+518(0.05)^{2}}$

$n=226$

The breakdown of the sample was proportional to the population, as shown in Table 1.

The sample consisted of $66 \mathrm{~A}_{1}$ producers, $84 \mathrm{~A}_{2}$ producers, 40 small-scale commercial producers, 6 large-scale commercial producers, 6 abattoirs and 24 retailers. A structured, standardised and pre-coded questionnaire was utilised to collect data pertaining to socio-economic and demographic statistics, the firms' pricing objectives and price flexibility policy. Data analysis methods used were descriptive statistics and logit model. SPSS version 23 was the analytical software used. Logit model was used to identify factors influencing the firm's pricing objective and price flexibility policies. The model is specified as follows: 


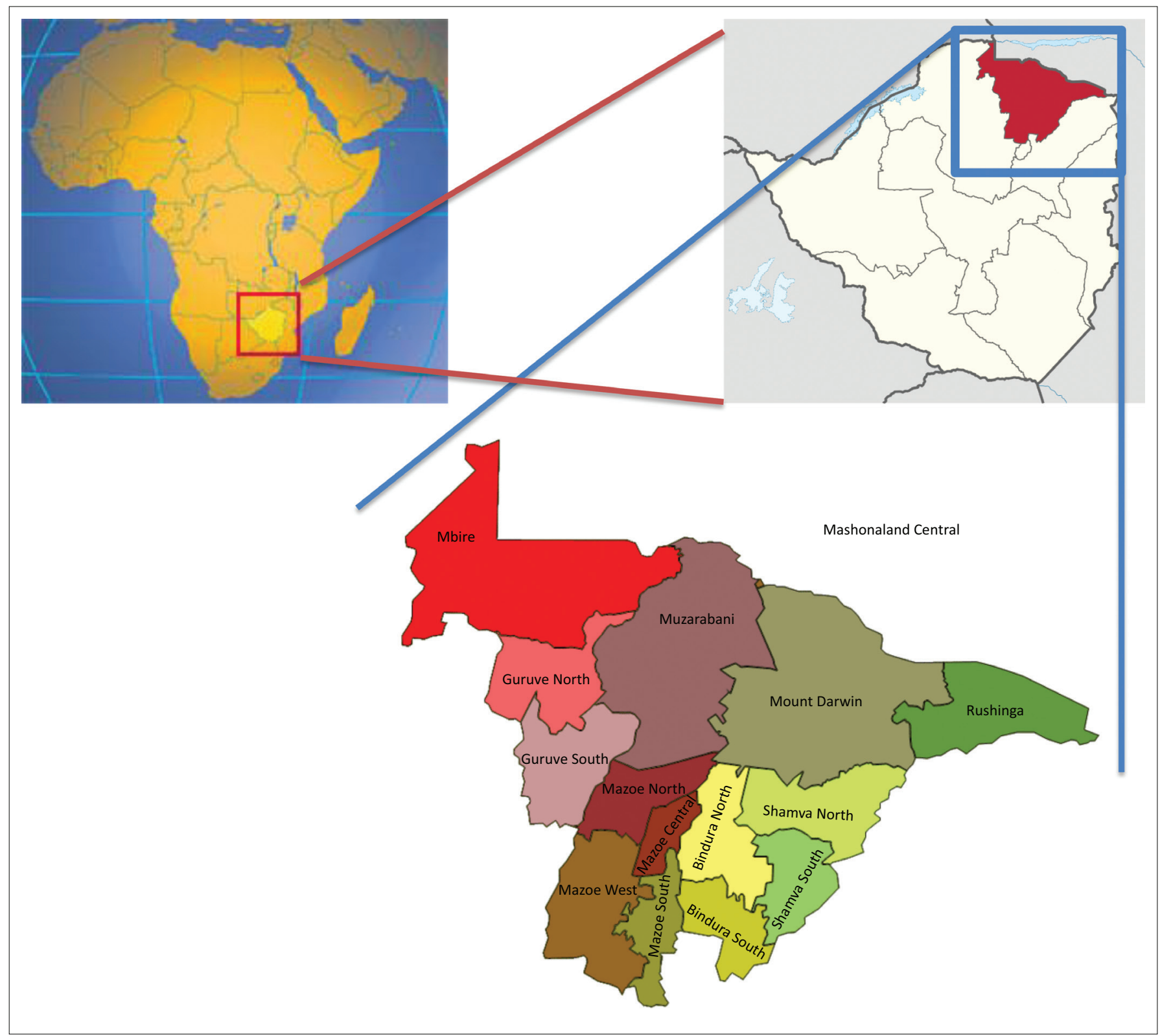

Source: Wikipedia, n.d., Mashonaland Central Province, viewed 27 April 2017, from https://en.wikipedia.org/wiki/Mashonaland_Central_Province; Nationsonline, n.d., Location map of Zimbabwe, viewed 27 April 2017, from http://www.nationsonline.org/oneworld/zimbabwe.htm

FIGURE 1: Geographical location of Mashonaland Central province.

\section{TABLE 1: Sample size.}

\begin{tabular}{|c|c|c|c|c|}
\hline Industry player & Population & Sought-after responses (sample) & Actual responses (sample) & $\%$ variance \\
\hline \multicolumn{5}{|l|}{ Producers: } \\
\hline$A_{1}$ & 152 & 66 & 56 & $-15.15 \%$ \\
\hline $\mathrm{A}_{2}$ & 193 & 84 & 66 & $-21.43 \%$ \\
\hline Small-scale & 92 & 40 & 38 & $-5 \%$ \\
\hline Large-scale & 14 & 6 & 6 & - \\
\hline Processors & 14 & 6 & 6 & - \\
\hline Retailers & 53 & 24 & 24 & - \\
\hline Total & 518 & 226 & 196 & $-13.27 \%$ \\
\hline
\end{tabular}

Source: Adapted from Zimbabwe National Statistics Agency (ZIMSTAT), 2014a, Agriculture and livestock survey: Small scale commercial farms: Large scale commercial farms: Communal lands: $A_{2}$ farms: $A_{1}$ farms, 2012, viewed 20 March 2017, from http://www.zimstat.co.zw

$\log \left(\frac{P_{(y=1)}}{1-P_{(y=1)}}\right)=\beta_{0}+\sum_{i=1}^{n} \beta_{i} \chi_{i}$ or as $\left(\frac{P_{(y=1)}}{1-P_{(y=1)}}\right)=e^{\left(\beta_{0}+\sum_{i=1}^{n} \beta_{i} \chi_{i}\right)}$

[Eqn 3]
$P$ is the probability that a profit objective is pursued, $y=0$, or a survival pricing objective is pursued, $y=1 ; X_{i}$ is the set of independent variables. In the second expression $\left(\frac{P_{(y=1)}}{1-P_{(y=1)}}\right)$ represents the odds ratio with $e^{\left(\beta_{0}+\sum_{i=1}^{n} \beta_{i} x_{i}\right)}$ 
representing the marginal effects of $X_{i}$ on the odds. Another logit was performed with $y=0$ being a flexible price policy is pursued, and $y=1$ being a one price policy is pursued. The explanatory variables and their expected signs are presented in Table 2. Each firm or farm was thus faced with a binary choice: profit-oriented or survival pricing objective as well as flexible or one price policy. The strategy choice of the firm or farm in this case being dependent on the various institutional and firm or farm-specific factors. Although four pricing objectives were being applied by the firms, sales and comparing with competition pricing objectives were assumed to be survival-based pricing objectives.

The resultant equation is presented as follows:

$$
\log \left(\frac{P_{(y=1)}}{1-P_{(y=1)}}\right)=\beta_{0}+\beta_{1} \chi_{1 i}+\beta_{2} \chi_{2 i}+\beta_{n} \chi_{i}
$$

\section{Results and discussion Demographic results}

Table 3 shows that $96.4 \%, 66.7 \%$ and $57.9 \%$ of the respondents in $\mathrm{A}_{1}, \mathrm{~A}_{2}$ and small-scale farms were owners of their agribusinesses respectively, while $66.7 \%$ of large-scale commercial farms and registered abattoirs respectively were involved in management of the agribusiness, with $62.5 \%$ and $72 \%$ of registered and unregistered butcheries respectively being supervisors in the agribusinesses. Forty-six per cent of $\mathrm{A}_{1}$ farmer respondents were aged 40 or older, as well as $57.9 \%$ small-scale commercial farm respondents and all the large-scale commercial farm respondents. Thirty-three per cent of $\mathrm{A}_{2}$ farm respondents were aged between 30 and 34, while $66.7 \%$ of registered abattoir respondents were aged between 35 and 39. Half of the unregistered and registered butcher respondents were aged between 25 and 29 .

TABLE 2: Variables used in the logistic regression model.

\begin{tabular}{|c|c|c|c|c|}
\hline Variable & Explanation & Definition & Type of measurement & Expected sign \\
\hline \multicolumn{5}{|c|}{ Dependent variable } \\
\hline$Y_{0}, Y_{1}$ & $\begin{array}{l}Y=0 ; \text { Profit-oriented pricing objective; } \\
Y=1 \text {; Survival-oriented pricing objective }\end{array}$ & $\begin{array}{l}\text { What pricing objective does your } \\
\text { agribusiness pursue? }\end{array}$ & $\begin{array}{l}\text { Dummy: } 0=\text { Profit-oriented pricing objective, } \\
1=\text { Survival-oriented pricing objective }\end{array}$ & - \\
\hline$Y_{0}, Y_{1}$ & $\begin{array}{l}Y=0 ; \text { Price flexibility policy; } \\
Y=1 \text {; One price policy }\end{array}$ & $\begin{array}{l}\text { What price flexibility policy does } \\
\text { your agribusiness pursue? }\end{array}$ & $\begin{array}{l}\text { Dummy: } 0 \text { = Price flexibility policy, } 1 \text { = One price } \\
\text { policy }\end{array}$ & - \\
\hline \multicolumn{5}{|c|}{ Independent variable } \\
\hline CAT & Category of agribusiness & $\begin{array}{l}\text { Under which category is your } \\
\text { agribusiness? }\end{array}$ & $\begin{array}{l}\text { Dummy: } 1=\mathrm{A}_{1} \text { farmer, } 2=\mathrm{A}_{2} \text { farmer, } 3=\text { Small-scale } \\
\text { commercial farmer, } 4=\text { Large-scale commercial farmer, } \\
5=\text { Registered abattoir, } 6=\text { Unregistered abattoir, } \\
7=\text { Registered butcher, } 8=\text { Unregistered butcher }\end{array}$ & \pm \\
\hline PPP & Pork product portfolio & $\begin{array}{l}\text { What is your pork product } \\
\text { portfolio? }\end{array}$ & $\begin{array}{l}\text { Dummy: } 1 \text { = baconer, } 2 \text { = porker, } 3 \text { = baconer and } \\
\text { porker }\end{array}$ & \pm \\
\hline MARG & Margin (profit to cost ratio) of agribusiness & What is your profit to cost ratio? & $\begin{array}{l}\text { Dummy: } 1=\text { less than } 0 \%, 2=0 \%-4 \%, 3=5 \%-9 \% \text {, } \\
4=10 \%-14 \%, 5=\text { more than } 14 \%, 6=\text { no idea }\end{array}$ & - \\
\hline LOC & Agribusiness location & $\begin{array}{l}\text { Where is your agribusiness } \\
\text { located? }\end{array}$ & Dummy: 1 = town, 2 = growth point, 3 = rural & \pm \\
\hline EXIST & Period of existence of the agribusiness & $\begin{array}{l}\text { How long has the agribusiness } \\
\text { been in existence? }\end{array}$ & $\begin{array}{l}\text { Dummy: } 1=\text { less than } 5 \text { years, } 2=5-9 \text { years, } 3=10-14 \\
\text { years, } 4=15 \text { years or more }\end{array}$ & - \\
\hline NUMPIG & $\begin{array}{l}\text { Average number of pigs or carcasses sold } \\
\text { or handled }\end{array}$ & $\begin{array}{l}\text { What is the average number of } \\
\text { pigs or carcasses sold or handled } \\
\text { in a month? }\end{array}$ & Dummy: $1=0-4,2=5-9,3=10-14,4=15$ and above & - \\
\hline WEIGPIG & Average weight of pork or pigs handled & $\begin{array}{l}\text { What is the average weight of pork } \\
\text { or pigs handled in } \mathrm{kg} \text { ? }\end{array}$ & $\begin{array}{l}\text { Dummy: } 1=\text { Less than } 20,2=20-39,3=40-59,4= \\
60-79,5=80 \text { and above }\end{array}$ & - \\
\hline DIST & Distance furthest buyer travels & $\begin{array}{l}\text { What distance does your furthest } \\
\text { buyer travel? }\end{array}$ & $\begin{array}{l}\text { Dummy: } 1=\text { Less than } 1 \mathrm{~km}, 2=1-9 \mathrm{~km}, 3=10 \mathrm{~km}-19 \\
\mathrm{~km}, 4=20 \mathrm{~km}-29 \mathrm{~km}, 5=30 \mathrm{~km} \text { and above }\end{array}$ & - \\
\hline FREQAB & Frequency of abattoir or processor buyers & $\begin{array}{l}\text { Frequency of abattoir or processor } \\
\text { buyers }\end{array}$ & Dummy: 1 = all the time, 2 = sometime, $3=$ never & \pm \\
\hline FREQRET & Frequency of retailer or butchery buyers & $\begin{array}{l}\text { Frequency of retailer or butchery } \\
\text { buyers }\end{array}$ & Dummy: 1 = all the time, 2 = sometime, $3=$ never & \pm \\
\hline FREQIND & Frequency of individual customer buyers & $\begin{array}{l}\text { Frequency of individual customer } \\
\text { buyers }\end{array}$ & Dummy: 1 = all the time, 2 = sometime, $3=$ never & \pm \\
\hline JANMARSA & January to March seasonality of sales & $\begin{array}{l}\text { January to March seasonality of } \\
\text { sales }\end{array}$ & $\begin{array}{l}\text { Dummy: } 1=\text { very high, } 2=\text { high, } 3=\text { average, } 4=\text { low, } \\
5=\text { very low }\end{array}$ & \pm \\
\hline APRJUNSA & April to June seasonality of sales & April to June seasonality of sales & $\begin{array}{l}\text { Dummy: } 1=\text { very high, } 2=\text { high, } 3=\text { average, } 4=\text { low, } \\
5=\text { very low }\end{array}$ & \pm \\
\hline JULSEPSA & July to September seasonality of sales & $\begin{array}{l}\text { July to September seasonality of } \\
\text { sales }\end{array}$ & $\begin{array}{l}\text { Dummy: } 1=\text { very high, } 2=\text { high, } 3=\text { average, } 4=\text { low, } \\
5=\text { very low }\end{array}$ & \pm \\
\hline OCTDECSA & October to December seasonality of sales & $\begin{array}{l}\text { October to December seasonality } \\
\text { of sales }\end{array}$ & $\begin{array}{l}\text { Dummy: } 1=\text { very high, } 2=\text { high, } 3=\text { average, } 4=\text { low, } \\
5=\text { very low }\end{array}$ & \pm \\
\hline SIZE & $\begin{array}{l}\text { Size of pig or carcass consideration when } \\
\text { selling pork or pig }\end{array}$ & $\begin{array}{l}\text { Do you consider size of pig or } \\
\text { carcass when selling your pig or } \\
\text { pork? }\end{array}$ & $\begin{array}{l}\text { Dummy: } 1 \text { = always considered, } 2=\text { almost always } \\
\text { considered, } 3=\text { sometimes considered, } 4=\text { rarely } \\
\text { considered, } 5=\text { never considered }\end{array}$ & - \\
\hline PRICEOTHPL & $\begin{array}{l}\text { Price of other industry players } \\
\text { consideration when selling pork or pig }\end{array}$ & $\begin{array}{l}\text { Do you consider price of other } \\
\text { industry players when selling your } \\
\text { pig or pork? }\end{array}$ & $\begin{array}{l}\text { Dummy: } 1 \text { = always considered, } 2 \text { = almost always } \\
\text { considered, } 3=\text { sometimes considered, } 4=\text { rarely } \\
\text { considered, } 5=\text { never considered }\end{array}$ & + \\
\hline QUALCONS & $\begin{array}{l}\text { Quality of pig or carcass consideration } \\
\text { when selling pork or pig }\end{array}$ & $\begin{array}{l}\text { Do you consider quality of pig or } \\
\text { carcass when selling your pigor } \\
\text { pork? }\end{array}$ & $\begin{array}{l}\text { Dummy: } 1 \text { = always considered, } 2=\text { almost always } \\
\text { considered, } 3=\text { sometimes considered, } 4=\text { rarely } \\
\text { considered, } 5=\text { never considered }\end{array}$ & - \\
\hline TIMECONS & $\begin{array}{l}\text { Time of year consideration when selling } \\
\text { pork or pig }\end{array}$ & $\begin{array}{l}\text { Do you consider time of year when } \\
\text { selling your pig or pork? }\end{array}$ & $\begin{array}{l}\text { Dummy: } 1 \text { = always considered, } 2=\text { almost always } \\
\text { considered, } 3=\text { sometimes considered, } 4=\text { rarely } \\
\text { considered, } 5=\text { never considered }\end{array}$ & \pm \\
\hline CONST & Constant & - & - & \\
\hline
\end{tabular}




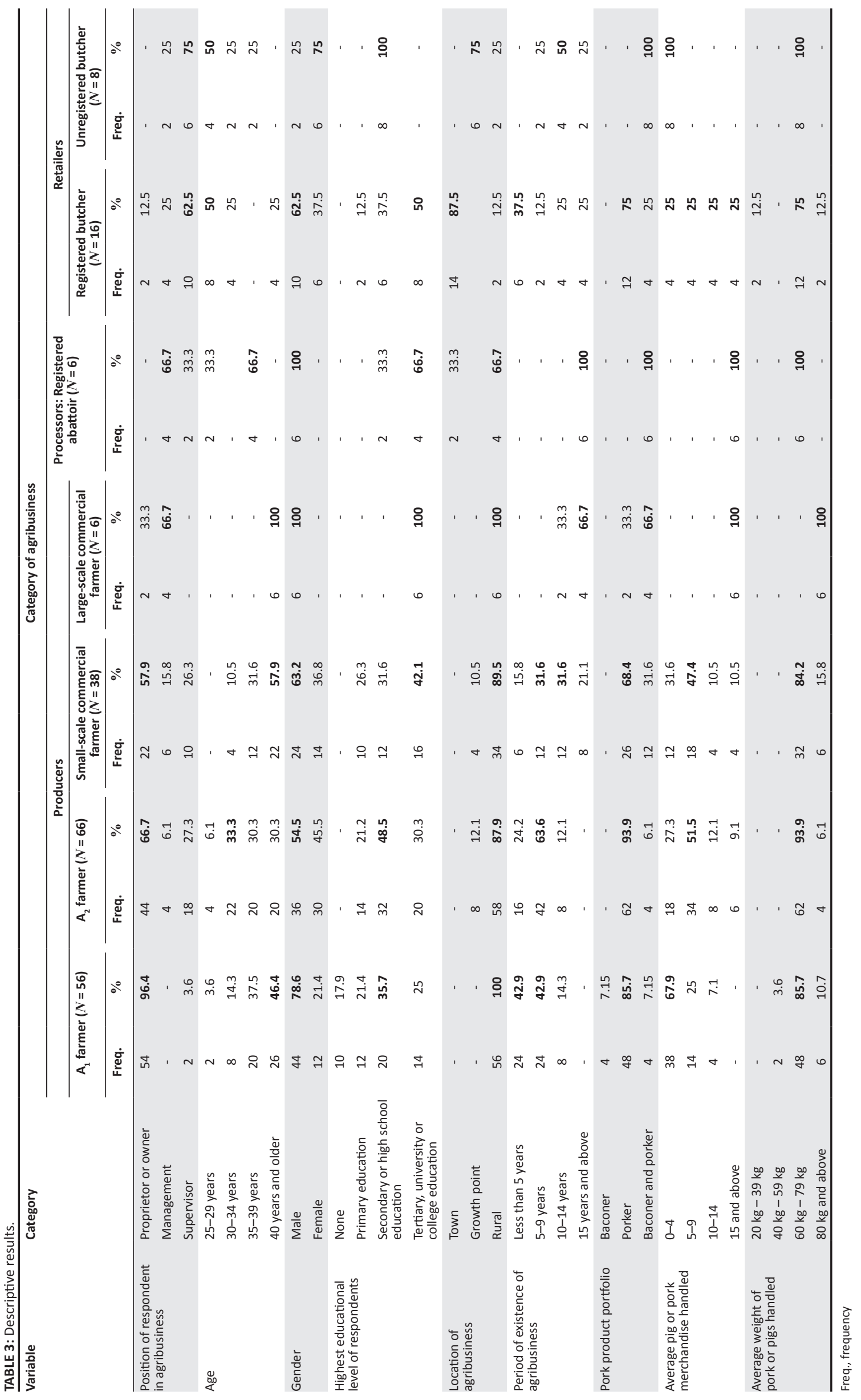


In all categories of agribusinesses, male respondents dominated except for unregistered butcheries which had 75\% of respondents being female. None of the respondents had educational levels below secondary or high school level, with $42.7 \%$ of small-scale commercial producers, all large-scale commercial producers, $66.7 \%$ registered abattoirs and 50\% registered butcher respondents attaining tertiary, university or college educational levels. Most of the pig producers and the registered abattoirs were located in rural areas, while $87.5 \%$ of registered butchers were in towns and $75 \%$ of unregistered butchers were located at growth points. All registered abattoirs had been in business for more than 15 years as well as $66.7 \%$ of large-scale commercial producers, with half of the unregistered butchers having between 10 and 14 years of experience, as well as $31.6 \%$ of small-scale commercial producers. Forty-three per cent, $63.6 \%$ and $31.6 \%$ of $\mathrm{A}_{1}, \mathrm{~A}_{2}$ and small-scale commercial producers respectively had between 5 and 9 years of experience, with $37.5 \%$ of registered butchers having been in existence less than 5 years.

Most of the producers and registered butchers were handling porkers, whereas all the abattoirs and unregistered butchers as well as $66.7 \%$ of large-scale commercial producers were handling both porkers and baconers. The average number of pork or pigs handled seems to vary, with all registered abattoirs and large-scale producers handling more than 15, whereas all unregistered butchers and $67.9 \%$ of $\mathrm{A}_{1}$ producers handling less than 5. Most agribusinesses handled merchandise averaging more than $60 \mathrm{~kg}$, with all large-scale commercial producers handling merchandise weighing more than $80 \mathrm{~kg}$.
Table 4 shows a significant and low association between pricing objectives and category of agribusiness as presented by $X^{2}$, Cramer's V and Spearman correlation at $p<0.01$. Half of the $\mathrm{A}_{1}$ farmers were pricing to survive in the industry as well as $52.6 \%$ of small-scale commercial farmers. However, all large-scale commercial producers, registered and unregistered butchers as well as $66.7 \%$ of registered abattoirs were aiming for a profit-oriented pricing objective.

Table 5 also shows significant and low association between price flexibility policy and category of agribusiness as presented by $X^{2}$ and Cramer's V at $p<0.01$. All unregistered butchers, $87.5 \%$ of registered butchers, $66.7 \%$ of registered abattoirs and $57.1 \%$ of $\mathrm{A}_{1}$ farmers utilise a one price policy, while $66.7 \%, 52.6 \%$ and $57.6 \%$ of large-scale commercial farmers, small-scale commercial farmers and $\mathrm{A}_{2}$ farmers respectively were utilising a flexible pricing policy.

\section{Empirical results}

Table 6 shows a significant relationship between choice of pricing objective and the variables utilised $\left(R^{2}=0.689\right)$. The variables utilised explain $68.9 \%$ of choice between profitoriented and survival-oriented pricing objectives. The most significant variables identified were pork product portfolio, margin, merchandise handled (both number and weight), distance the furthest buyer travels and consideration of pricing by other industry players at the $p<0.01$ level. Other variables such as seasonality of sales in July to September as well as quality of pork consideration were significant at the $p<0.05$ level, while frequency of retailer buyers, seasonality

TABLE 4: Cross-tabulation of pricing objectives and category of agribusiness.

\begin{tabular}{|c|c|c|c|c|c|c|c|c|c|c|c|c|c|c|c|c|}
\hline \multirow[t]{4}{*}{ Variable } & \multirow[t]{4}{*}{ Category } & \multicolumn{14}{|c|}{ Category of agribusiness } & \multirow{4}{*}{$\begin{array}{l}\text { Summary } \\
\\
- \\
\end{array}$} \\
\hline & & \multicolumn{8}{|c|}{ Producers } & \multirow{2}{*}{\multicolumn{2}{|c|}{$\begin{array}{c}\text { Processors: } \\
\text { Registered } \\
\text { abattoir }(N=6)\end{array}$}} & \multicolumn{4}{|c|}{ Retailers } & \\
\hline & & \multicolumn{2}{|c|}{$\begin{array}{l}\text { A }_{1} \text { farmer } \\
(N=56)\end{array}$} & \multicolumn{2}{|c|}{$\begin{array}{c}\mathrm{A}_{2} \text { farmer } \\
(N=66)\end{array}$} & \multicolumn{2}{|c|}{$\begin{array}{c}\text { Small-scale } \\
\text { commercial } \\
\text { farmer }(N=38)\end{array}$} & \multicolumn{2}{|c|}{$\begin{array}{c}\text { Large-scale } \\
\text { commercial } \\
\text { farmer }(N=6)\end{array}$} & & & \multicolumn{2}{|c|}{$\begin{array}{c}\text { Registered } \\
\text { butcher }(N=16)\end{array}$} & \multicolumn{2}{|c|}{$\begin{array}{c}\text { Unregistered } \\
\text { butcher } \\
(N=8)\end{array}$} & \\
\hline & & Freq. & $\%$ & Freq. & $\%$ & Freq. & $\%$ & Freq. & $\%$ & Freq. & $\%$ & Freq. & $\%$ & Freq. & $\%$ & \\
\hline \multirow{3}{*}{$\begin{array}{l}\text { Pricing } \\
\text { objective }\end{array}$} & Profit & 26 & 46.4 & 32 & 48.5 & 18 & 47.4 & 6 & 100 & 4 & 66.7 & 16 & 100 & 8 & 100 & - \\
\hline & Sales & - & - & 12 & 18.2 & - & - & - & - & - & - & - & - & - & - & - \\
\hline & Survive & 28 & 50 & 22 & 33.3 & 20 & 52.6 & - & - & 2 & 33.3 & - & - & - & - & - \\
\hline \multirow[t]{3}{*}{ Summary } & $X^{2}$ & - & - & - & - & - & - & - & - & - & - & - & - & - & - & $57.733 *$ \\
\hline & Cramer's V & - & - & - & - & - & - & - & - & - & - & - & - & - & - & $0.313 *$ \\
\hline & $\begin{array}{l}\text { Spearman's } \\
\text { correlation }\end{array}$ & - & - & - & - & - & - & - & - & - & - & - & - & - & - & $-0.258 *$ \\
\hline
\end{tabular}

*, Significant at $10 \%$

TABLE 5: Cross-tabulation of price flexibility policy and category of agribusiness

\begin{tabular}{|c|c|c|c|c|c|c|c|c|c|c|c|c|c|c|c|c|}
\hline \multirow[t]{4}{*}{ Variable } & \multirow[t]{4}{*}{ Category } & \multicolumn{14}{|c|}{ Category of agribusiness } & \multirow{4}{*}{$\begin{array}{l}\text { Summary } \\
\\
-\end{array}$} \\
\hline & & \multicolumn{8}{|c|}{ Producers } & \multirow{2}{*}{\multicolumn{2}{|c|}{$\begin{array}{c}\text { Processors: } \\
\text { Registered } \\
\text { abattoir }(N=6)\end{array}$}} & \multicolumn{4}{|c|}{ Retailers } & \\
\hline & & \multicolumn{2}{|c|}{$\begin{array}{l}\text { A }_{1} \text { farmer } \\
(N=56)\end{array}$} & \multicolumn{2}{|c|}{$\begin{array}{c}\text { A }_{2} \text { farmer } \\
(N=66)\end{array}$} & \multicolumn{2}{|c|}{$\begin{array}{c}\text { Small-scale } \\
\text { commercial } \\
\text { farmer }(N=38)\end{array}$} & \multicolumn{2}{|c|}{$\begin{array}{c}\text { Large-scale } \\
\text { commercial } \\
\text { farmer }(N=6)\end{array}$} & & & \multicolumn{2}{|c|}{$\begin{array}{l}\text { Registered butcher } \\
\qquad(N=16)\end{array}$} & \multicolumn{2}{|c|}{$\begin{array}{l}\text { Unregistered } \\
\text { butcher }(N=8)\end{array}$} & \\
\hline & & Freq. & $\%$ & Freq. & $\%$ & Freq. & $\%$ & Freq. & $\%$ & Freq. & $\%$ & Freq. & $\%$ & Freq. & $\%$ & \\
\hline \multirow{2}{*}{$\begin{array}{l}\text { Pricing } \\
\text { objective }\end{array}$} & Price flexibility & 24 & 42.9 & 38 & 57.6 & 20 & 52.6 & 4 & 66.7 & 2 & 33.3 & 2 & 12.5 & - & - & - \\
\hline & One price & 32 & 57.1 & 28 & 42.4 & 18 & 47.4 & 2 & 33.3 & 4 & 66.7 & 14 & 87.5 & 8 & 100 & - \\
\hline \multirow{2}{*}{ Summary } & Cramer's V & - & - & - & - & - & - & - & - & - & - & - & - & - & - & $0.319 *$ \\
\hline & $\begin{array}{l}\text { Spearman's } \\
\text { correlation }\end{array}$ & - & - & - & - & - & - & - & - & - & - & - & - & - & - & 0.112 \\
\hline
\end{tabular}

*, Significant at $1 \%$. 
TABLE 6: Empirical binary logistic results of choice of pricing objectives.

\begin{tabular}{|c|c|c|c|c|}
\hline Variable & B & Sig. & $\operatorname{Exp}(B)$ & Model summary \\
\hline Category of agribusiness & 0.233 & 0.503 & 1.262 & - \\
\hline Pork product portfolio & $2.195 * * *$ & 0.006 & 8.984 & - \\
\hline Margin (profit to cost ratio) of agribusiness & $-1.099 * * *$ & 0.003 & 0.333 & - \\
\hline Agribusiness location & 23.048 & 0.994 & $10.21 \mathrm{E}+7$ & - \\
\hline Period of existence of the agribusiness & 0.418 & 0.263 & 1.519 & - \\
\hline Average number of pigs or carcasses sold or handled in a month & $-1.283^{* * *}$ & 0.002 & 0.277 & - \\
\hline Average weight of pork or pigs handled & $-3.427 * * *$ & 0.000 & 0.032 & - \\
\hline Distance furthest buyer travels & $3.547 * * *$ & 0.003 & 34.712 & - \\
\hline Frequency of abattoir or processor buyers & -0.447 & 0.367 & 0.639 & - \\
\hline Frequency of retailer or butchery buyers & $-1.886 *$ & 0.074 & 0.152 & - \\
\hline Frequency of individual customer buyers & -0.927 & 0.249 & 0.396 & - \\
\hline January to March seasonality of sales & -0.441 & 0.458 & 0.644 & - \\
\hline April to June seasonality of sales & $1.375^{*}$ & 0.093 & 3.955 & - \\
\hline July to September seasonality of sales & $-1.537 * *$ & 0.031 & 0.215 & - \\
\hline Size of pig or carcass consideration when selling pork or pig & $3.655^{*}$ & 0.066 & 38.677 & - \\
\hline Price of other industry players consideration when selling pork or pig & $1.027 * * *$ & 0.009 & 2.793 & - \\
\hline Quality of pig or carcass consideration when selling pork or pig & $-2.462 * *$ & 0.031 & 0.085 & - \\
\hline Time of year consideration when selling pork or pig & 0.647 & 0.112 & 1.910 & - \\
\hline Constant & -73.798 & 0.994 & 0.000 & - \\
\hline$X^{2}$ & - & - & - & $141.411 * * *$ \\
\hline (-2) log likelihood & - & - & - & 127.356 \\
\hline Nagekerke $R^{2}$ & - & - & - & 0.689 \\
\hline
\end{tabular}

*, Significant at $10 \% ; * *$, Significant at $5 \% ; * * *$, Significant at $1 \%$

$B$, beta; Sig., significance; $\operatorname{Exp}(B)$, exponentiation of the B coefficient.

of sales in April to June and size of carcass consideration were significant at the $p<0.1$ level.

Table 6 shows that pork product portfolio has a positive coefficient, signifying that as industry players shift from handling porkers, baconers and combining both, they are eight times more likely to utilise survival pricing objectives. ULYSSES (2014) found this as a strategy option in Germany where farmers would wait a bit and sell at a survival price, while wholesalers would sell quickly at a survival price. However, this was contrary to Teklewold et al. (2009) who found profit-oriented pricing objectives as the pork product portfolio transcended in Ethiopia. This is also true for the distance travelled by the furthest buyer, showing that as the distance increases, industry players are 34 times more likely going to choose survival pricing objectives. This could be due to the ever-diminishing customer base as the distance from the agribusiness increases. As such, the objective of the agribusiness will tend to shift towards survival. As the April to June sales diminish, industry players are nine times more likely to opt for survival pricing objectives. This is similar to UM (2013) who identified medium to high consideration of seasonality on pricing strategies pursued at all stages of the meat market along a value chain. In Ethiopia, Teklewold et al. (2009) found that seasonality in terms of precipitation as well as sync with religious events were major determinants in the price formation decisions. Seasonality swaying pricing objectives towards survival may also be explained by the low availability of complementary feed especially during dry periods thereby reducing animal body condition. Diminishing sales equate to diminishing ability to break even necessitating agribusinesses to shift from profit orientation to survival pricing objectives. This is also observed when the size of carcass consideration diminishes: industry players will opt for survival pricing objectives. The smaller the size, the lower the returns especially when the size of the enterprise is taken into consideration. This prompts agribusinesses to opt for survival pricing objectives.

However, the more merchandise handled in a month (both in number and weight) the more likely that industry players will shift from survival pricing policies towards profitoriented. Mussell et al. (2003) exemplify this when they find volume specification weeks or months before sale, with the objective of maximising returns in Canada. This was, however, in contrast to ULYSSES (2014) who indicated that because of the difficulty in keeping pigs, especially at the farmer level, firms utilise a survival pricing objective to minimise losses. There is a $72.3 \%$ and $96.8 \%$ likelihood of this happening when the number and weight of merchandise respectively are considered. This is also observed for the margin, where there is a $66.7 \%$ chance that, as the profit to cost ratio increases, industry players will opt for profit-oriented pricing objectives. Mutambara and Chingozho (2011) found low demand for pork being one of the non-regulatory constraints in the Zimbabwean pork industry, perpetuated by inability to secure external markets with production levels kept minimal. However, the low demand for pork product in Zimbabwe as highlighted by Mutambara and Chingozho (2011) has shown a positive shift mainly due to the high prices of beef substitutes. Due to economies of scale as well, as the output and merchandise increases, the costs of production are more easily covered, shifting from survival to profit objectives. As a result, the industry aims to maximise as much as possible in this local market through profit maximisation. As sales from July to September decrease, there is a $66.9 \%$ chance that 
industry opts for a profit-oriented pricing objective. This can be due to the speculative tendencies of the industry in anticipation of the heightened business in the following quarter of the year, with festivities. Profit-oriented pricing objectives are also $66.9 \%$ likely to be preferred when the quality of the pork or pig is lowly considered by industry players. Purcell (1997) indicates the subjective nature of quality determination in price discovery systems. Teklewold et al. (2009) also found the age group and body condition of traded animals having an influence on price formation in Ethiopia. Opting for a survival-oriented pricing objective can be due to the low quality of pork products in the country. Mutambara and Chingozho (2011) identified a poor quality breeding stock in the Zimbabwean pork industry, compromising the quality. This speaks directly to consumers who tend to consider quality in terms of place of purchase and physical appearance (Dransfield et al. 2005; Ngapo et al. 2003; UM 2013). The industry players therefore feel inclined to survive in the industry, which cannot supply the export market because of the low quality.

Table 7 shows a significant relationship between choice of price flexibility policy and the variables utilised $\left(R^{2}=0.391\right)$. The variables utilised explain $39.1 \%$ of choice between price flexibility and one price policy. The most significant variables identified were agribusiness location, average weight of merchandise, frequency of individual customers and consideration of size of carcass and price of other industry players at the $p<0.01$ level. Other variables such as margin and frequency of abattoir buyers were significant at the $p<0.05$ level, while pork product portfolio was significant at the $p<0.1$ level.

Table 7 shows that as the profit to cost ratio increases, industry players are 1.7 times more likely to utilise a one price policy. This is also true for the average weight of merchandise handled, where an increase in weight will increase the likelihood of a one price policy utilisation 4.1 times. This is consistent with Mussell et al.'s (2003) findings in Canada of a similar pricing mechanism when the volume and quality risk were taken into consideration. This might be due to industry players initially producing to cover their costs of production thereby being flexible in their pricing, but once this objective is met, they then stick to one price, most observed at the producer level. The increased demand for pork products might also induce utilisation of a one price policy especially at the retail level. The frequencies of abattoir buyer increasing will likely double the utilisation of a one price policy, while frequency of individual customers increasing has a 5.3 likelihood of a one price policy being utilised. This can be explained by the low merchandise volumes that individual customers handle. This reduces incentive to offer a flexible price had they handled more merchandise. However, an alternative explanation at the abattoir level can be the enhanced confidence of having a market and return by the industry players, thereby reducing necessity of offering varied prices.

However, as the pork product portfolio shifts from porker to baconer and a combination of both, there is a $65 \%$ chance that a flexible price will be utilised. This finding is similar to Teklewold et al. (2009) in Ethiopia, who identified buyer and seller type attributes being significant factors influencing price formation. This can be a reflection of the output from the industry, where most of the industry players concentrate on porkers relative to baconers. This is due to the relatively shorter time required to mature porkers relative to baconers. Therefore, industry players are more prepared to compromise on utilising a flexible price to push merchandise than in baconer production. There also exists a $91.2 \%$ chance that as agribusiness location shifts from town to growth point and rural, the more likely they will utilise a flexible pricing policy. This is consistent with Mussell's (2003) findings that in Canada, the pricing mechanism was area specific. This can

TABLE 7: Empirical binary logistic results of choice of price flexibility policy.

\begin{tabular}{|c|c|c|c|c|}
\hline Variable & B & Sig. & $\operatorname{Exp}(B)$ & Model summary \\
\hline Category of agribusiness & 0.342 & 0.160 & 1.408 & - \\
\hline Pork product portfolio & $-1.049 *$ & 0.059 & 0.350 & - \\
\hline Margin (profit to cost ratio) of agribusiness & $0.512 * *$ & 0.048 & 1.668 & - \\
\hline Agribusiness location & $-2.428 * * *$ & 0.001 & 0.088 & - \\
\hline Period of existence of the agribusiness & -0.239 & 0.310 & 0.787 & - \\
\hline Average number of pigs or carcasses sold/handled in a month & -0.393 & 0.121 & 0.675 & - \\
\hline Distance furthest buyer travels & -0.506 & 0.467 & 0.603 & - \\
\hline Frequency of abattoir or processor buyers & $0.675 * *$ & 0.031 & 1.964 & - \\
\hline Frequency of retailer or butchery buyers & 0.508 & 0.408 & 1.661 & - \\
\hline Frequency of individual customer buyers & $1.680 * * *$ & 0.003 & 5.368 & - \\
\hline Size of pig/carcass consideration when selling pork or pig & $-1.702 * * *$ & 0.004 & 0.182 & - \\
\hline Price of other industry players consideration when selling pork or pig & $-0.617 * * *$ & 0.008 & 0.540 & - \\
\hline Quality of pig/carcass consideration when selling pork or pig & 0.421 & 0.393 & 1.523 & - \\
\hline Constant & 3.033 & 0.533 & 20.762 & - \\
\hline$X^{2}$ & - & - & - & $67.760 * * *$ \\
\hline$(-2)$ log likelihood & - & - & - & 202.646 \\
\hline Nagekerke $R^{2}$ & - & - & - & 39.1 \\
\hline
\end{tabular}

$*$, Significant at $10 \% ; * *$, Significant at $5 \% ; * * *$, Significant at $1 \%$

$B$, beta; Sig., significance; $\operatorname{Exp}(B)$, exponentiation of the $B$ coefficient. 
be due to the reduced market size in the rural areas, thereby necessitating that industry players be flexible in their pricing. Carricano (2014) found consideration of competitor pricing being a determinant of pricing strategies. Decreased consideration of size of carcass and quality of pork or pig when selling had an $81.1 \%$ and $46 \%$ chance respectively that a flexible pricing policy will be utilised. Lower quality and smaller size will negatively affect sales, thereby necessitating industry players to use flexible pricing.

\section{Conclusions}

Pricing mechanisms in pork industries tend to become more specialised, creative and complicated as the product moves from producer to retailer. The Zimbabwean pork industry is pursuing profit, sales, comparing with the competition as well as survival pricing objectives. The firms are also utilising both one price and flexible price policies. As the pork product moves down the value chain, the pricing objectives tend to shift from survival to profitoriented. There is also a shift from flexible pricing to one price policy as the pork product moves down the value chain. The agribusiness pricing objectives have been shown to be determined by the product portfolio, margin, merchandise handled, distance the furthest buyer travels and consideration of other industry players' pricing. Furthermore, factors such as seasonality in April to September sales, quality considerations, frequency of retailers and size considerations were also significant determinants of pricing objectives. Equally, the price flexibility policy pursued by agribusinesses has been shown to be determined by agribusiness location, average weight of merchandise, frequency of individual customers and size consideration. In addition, margin, frequency of abattoir buyers as well as pork product portfolio were also observed to be major factors towards a flexible pricing policy.

\section{Recommendations}

The study recommends that pork industry players shift from narrowly focused pricing objectives of profit and survival and devise new pricing strategies based on sales and comparing with the competition. There is need for combinational use of these pricing mechanisms than rather over-reliance on one. There is also need for less rigidity in price flexibility policies to take advantage of the dynamic external environment.

\section{Acknowledgements}

The authors acknowledge the immense contribution of Mr Shoniwa from the Pig Industry Board in locating the respondents used in the study.

\section{Competing interests}

The authors declare that they have no financial or personal relationship(s) that may have inappropriately influenced them in writing this article.

\section{Authors' contributions}

S.N. was responsible for formulating the introduction and problem statements as well as the methodology whereas A.M. was responsible for the analysis and discussion, as well as proofreading.

\section{References}

Adugna, T., 2006, 'Determinants of market prices of cattle in eastern Ethiopia', paper presented at the International Association of Agricultural Economists Conference, Gold Coast, Australia, 12-18 August.

African statistics year book, 2014, viewed from https://www.afdb.org/fileadmin/ uploads/afdb/.../African_Statistical_Yearbook_2014.pdf

Bakucs, L.Z. \& Ferto, I., 2005, 'Marketing margins and price transmission on the Hungarian Pork Market', Agribusiness 21(2), 273-286. https://doi.org/10.1002/ agr.20047

Bakucs, Z., Falwoski, J. \& Ferto, I., 2013, 'Does market structure influence price transmission in the agro-food sector? A meta-analysis perspective', Journal of Agricultural Economics 65, 1-25. https://doi.org/10.1111/1477-95.12042

Barnard, F., Akridge, J., Dooley, F. \& Foltz, J., 2012, Agribusiness management, 4th edn., Routledge, Taylor and Francis Group, London.

Bojnec, S., 2002, 'Price transmission and marketing margins in the Slovenian beef and pork markets during transition', paper presented at The X. Congress of European Association of Agricultural Economists, Zaragoza, Spain, 27-31 August.

Buhr, B.L., 2004, 'Case studies of direct marketing value-added pork products in a commodity market', Review of Agricultural Economics 26(2), 266-279. https:// doi.org/10.1111/j.1467-9353.2004.00175.x

Buhr, B.L. \& Kunkel, P.L., 1999, A guide to swine marketing contracts, University of Minnesota, Department of Applied Economics, St. Paul, MN.

Carricano, M., 2014, 'Pricing myopia: Do leading companies capture the full value of their pricing strategies?', Management Decision 52(1), 159-178. https://doi. org/10.1108/MD-03-2013-0184

Chazovachii, B., 2012, 'Piggery production and the empowerment of rural people in ward 21 of Gutu District, Masvingo Province, Zimbabwe', Journal of Sustainable Development in Africa 14(3), 164-179.

Chikweche, T. \& Fletcher, R., 2012, 'Revisiting the marketing mix at the Bottom of Pyramid (BOP): From theoretical considerations to practical realities', Journa of Consumer Marketing 29(7), 507-520. https://doi.org/10.1108/073637612 11275018

Chisango, F.F.T., 2010, 'Agricultural mechanization for sustainable agriculture and food security in Zimbabwe: A case of Bindura District in Mashonaland Central Province', unpublished MSc thesis in Agricultural Economics, Department of Agricultura Economics and Extension, Faculty of Science and Agriculture, University of Fort Hare.

De Toni, D., Milan, G.S., Saciloto, E.V. \& Larentis, F., 2016, 'Pricing strategies and levels and their impact on corporate profitability', Revista de Administração 52, 120 133. https://doi.org/10.1016/j.rausp.2016.12.004

Dodor, A., 2013, 'Using the 4P's to market staple farm produce in developing countries', Online Journal of Social Sciences Research 2(7), 220-224.

Dransfield, E., Ngapo, T.M., Nielsen, N.A., Bredahl, L., Sjödén, P.O., Magnusson, M. et al., 2005, 'Consumer choice and suggested price for pork as influenced by its appearance, taste and information concerning country of origin and organic pig production', Meat Science 69(1), 61-70. https://doi.org/10.1016/j.meatsci.2004.06.006

Dwyer, F.R. \& Tanner, J.F., Jr., 2003, Business marketing: Connecting strategy, relationships and learning, McGraw-Hill, New York, NY.

FAOSTAT, 2014, Zimbabwe FAO STAT - Economic indicators, Food and Agricultura Organization Statistics (FAOSTAT), Rome, Italy.

Hinterhuber, A., 2004, 'Towards value-based pricing: An integrative framework for decision making', Journal of Industrial Marketing Management 33, 765-778. https://doi.org/10.1016/j.indmarman.2003.10.006

Indounas, K., 2006, 'Making effective pricing decisions', Business Horizons 49, 415424.

Ingenbleek, P., 2007, 'Value informed pricing in its organizational context: Literature review, conceptual framework and directions for future research', Journal of Product and Brand Management 16(7), 441-458. https://doi.org/10.1108/10610 420710834904

Ingenbleek, P.T.M., Frambach, R.T. \& Verhallen, T.M.M., 2010, 'The role of valueinformed pricing in market-oriented product innovation management' Journal of Product Innovation and Management 27, 1032-1046. https://doi.org/10.1111/ j.1540-5885.2010.00769.x

Jumah, A., 2000, The long run, market power and retail pricing, Economics Series No. 78, Institute of Advanced Studies, Vienna.

Kenyon, D. \& Purcell, W., 1999, Price discovery and risk management in industrialized pork sector, Research Institute on Livestock, Blacksburg, VA.

Khumalo, T., 2014, Senior Zimbabwe meat industry figures call for cost reductions to aid exports, Ceaser Mhukahuru for Global and Meat Processing (13 October) viewed 06 December 2016 from www.globalmeatnews.com/industry-Markets.

Kotler, P., 2002, Marketing management: Millennium edition, Pearson's Custom Publishing, New Jersey, NJ 
Kotler, P., Armstrong, G., Saunders, J. \& Wong, V., 1999, Principles of marketing, 2nd European edn., Prentice Hall Europe, Essex.

Li, C. \& Sexton, R.J., 2013, 'Grocery-retailer pricing behaviour with implications for farmer welfare', Journal of Agricultural and Resource Economics 38(2), 141-158.

Mbogoh, S.G., 1992, 'Marketing options for livestock products: A total systems cummanagerial perspective', in J.A. Kategile \& S. Mubi (eds.), 'Future of livestock industries in east and southern Africa': Proceedings of the Workshop held at Kadoma Ranch, Zimbabwe, July 20-23, pp. 88-95.

McDaniel, C., Lamb, C.W. \& Hair, J., Jr., 2008, Introduction to marketing, 9th edn. Thomson South Western, Mason, $\mathrm{OH}$.

McGlone, J.J., 2013, 'The future of pork production in the world: Towards sustainable, welfare - Positive systems', Animals 3, 401-415. https://doi.org/10.3390/ ani3020401

Musemwa, L., 2011, 'Economics of land reform models used in Mashonaland Central Province of Zimbabwe', unpublished PhD thesis in Agricultural Economics, Department of Agricultural Economics and Extension, Faculty of Science and Agriculture, University of Fort Hare.

Mussell, A., 2003, Price discovery and alternatives for Canadian agriculture part III: Applying pricing mechanisms, George Morris Centre, Guelph.

Mussell, A., Mayer, H., Martin, L., Grier, K. \& Westgreen, R., 2003, Price discovery and alternatives for Canadian agriculture part I: A review of pricing mechanisms in agriculture, George Morris Centre, Guelph.

Mutambara, J., 2013, 'Non regulatory constraints affecting pig industry in Zimbabwe', Online Journal of Animal and Feed Research 3(1), 62-67.

Mutambara, J. \& Chingozho, D., 2011, Constraints affecting pig competitiveness, Pig Sector Issue Paper, October, Government of Zimbabwe, Harare.

Nationsonline, n.d., Location map of Zimbabwe, viewed 27 April 2017, from http:// www.nationsonline.org/oneworld/zimbabwe.htm

Netherlands Ministry of Economic Affairs, 2014, Agribusiness in Zimbabwe: Opportunities for economic cooperation, Netherlands Ministry of Economic Affairs, The Hague, Netherlands.

Ngapo, T.M., Dransfield, E., Martin, J.F., Magnusson, M., Bredahl, L. \& Nute, G.R. 2003, 'Consumer perceptions: Pork and pig production. Insights from France, England, Sweden and Denmark', Meat Science 66, 125-134. https://doi.org/ 10.1016/S0309-1740(03)00076-7

Ngarava, S., 2016, 'Effectiveness of commodity pricing along the pork value chain in Zimbabwe: A case of Mashonal and Central Province', unpublished MS Agricultural Economics thesis, Department of Agricultural Economics and Extension, Faculty of Science and Agriculture, University of Fort Hare.

Njaya, T., 2014, 'Operations of street vendors and their impact on sustainable urban life in high density suburbs of Harare, Zimbabwe', Asian Journal of Economic Modelling 2(1), 18-31.

Perreault, N.D. Jr \& McCarthy, F.J., 2002, Basic marketing: A global manageria approach, McGraw-Hill, New York, NY.

Pica-Ciamarra, U., Baker, D., Morgan, N., Ly, C. \& Noula, S., 2013, Investing in African livestock: Business opportunities in 2030-2050, Livestock Data Innovation in Africa Project, World Bank, FAO, ILRI \& AU-IBAR.

Purcell, W., 1997, Price discovery in concentrated livestock markets: Issues, answers, future direction, Research Institute on Livestock Pricing, Virginia Tech, Blacksburg, VA.

Schinckel, A., 2005, 'Management of pigs in the pork production chain', in Proceedings of the 5th London Swine Conference-Production at the Leading Edge, Ontario, London, 6-7 April.
Scoones, I., 2008, Retail revolutions and the rise of butcheries and informal selling in Zimbabwe, in Scoone, I., 2014, Debating Zimbabwe's land reform, Institute of Development Studies, Brighton.

Shao, R. \& Roe, B., 2002, 'The design and pricing of fixed and moving window contracts: An application of Asian-basket option pricing methods to the hog finishing sector', in American Agricultural Economics Annual Meetings, Long Beach, CA, 28-31 July.

Shipley, D. \& Jobber, D., 2001, 'Integrative pricing via the pricing wheel', Industrial Marketing Management 30, 301-314. https://doi.org/10.1016/S0019-8501(99) 00098-X

Smit, L.M., 2012, 'A framework for an affordable pricing strategy at The Central University of Technology, Free State', DTech thesis, CUT, Bloemfontein, p. 384.

Tawonezvi, P., Makuza, S., Moyo, S. \& Nengomasha, E., 2004, Country report on the state of animal genetic resources, FAO, Rome, viewed from http://ftp.fao.org/ docrep/fao/011/a1250f/annexes/CountryReports/Zimbabwe.pdf

Teklewold, H., Legese, G., Alemu, D. \& Negasa, A., 2009, 'Determinants of livestock prices in Ethiopian pastoral livestock markets: Implications for pastoral marketing strategies', in Contributed Paper for The International Association of Agricultural Economics Conference, Beijing, China, 16-22 August, 1-16.

ULYSSES, 2014, Agro-food chain actors' perception of price volatility and their management strategies, ULYSSES Food Price Volatility, Project 312182, Madrid.

UM, 2013, Meat marketing planner: Strategic marketing for farm to table meat enterprises, University of Maryland, Extension Bulletin EB 403, College Park, MD.

Unterschultz, J., Novak, F., Bresee, D. \& Koontz, S., 1997, 'Design and pricing of short term hog marketing contracts', in Proceedings of the NCR-134 Conference on Applied Price Analysis, Forecasting and Market Risk Management, Chicago, IL, 21-22 April, viewed from www.farmdoc.illinois.edu/nccc134

Uva, W.L., 2009, Smart pricing strategies, Virginia Cooperative Extension, Virginia State University, Petersburg, VA, viewed from http://www.ext.vt.edu

Volpe, R., Risch, C. \& Boland, M., 2015, The determinants of price adjustments in retail supermarkets, Managerial and Decision Economics, Wiley Online Library, viewed 06 February 2017, from http://www.wileyonlinelibrary.com

Von Braun, J., 2010, 'The role of livestock production for a growing world population' in Keynote Address at the 9th World Congress on Genetics Applied to Livestock Production, Leipzig, Germany, 01 August, Lohmann Information 45(2), 3-9.

Ward, C.E., Feuz, D.M. \& Schroeder, T.C.,1999, Formula pricing and grid pricing fed cattle: Implications for price discovery and variability, Research Institute on Livestock Pricing, Blacksburg, VA, pp. 1-99.

Wikipedia, n.d., Mashonaland Central Province, viewed 27 April 2017, from https:// en.wikipedia.org/wiki/Mashonaland_Central_Province

World Trade Organization (WTO), 2011, Trade policy review: Zimbabwe, October 19 and 21, WT/PR/S/252, viewed 02 May 2017, from www.wto.org/english/ tratop_e/tpr_e/tp352_e.htm

Yamane, T., 1967, Statistics: An introductory analysis, 2nd edn., Harper and Row, New York.

Zimbabwe National Statistics Agency (ZIMSTAT), 2014a, Agriculture and livestock survey: Small scale commercial farms: Large scale commercial farms: Communal lands: $A_{2}$ farms: $A_{1}$ farms, 2012, viewed 20 March 2017, from http://www.zimstat. lands: $A_{2}$

Zimbabwe National Statistics Agency (ZIMSTAT), 2014b, Census 2012: Provincia report: Mashonaland central, viewed 14 March 2017, from http://www.zimstat. co.zW 